\title{
The nature of 'document work', and its implications for radical community archives and their holdings
}

Steve Wright
Senior Lecturer, Faculty of Information Technology, Monash University, Australia

Corresponding Author.

Around fifty years ago, much of the world experienced a new cycle of mass social unrest. In their wake, the movements of that time have left a mass of records and other documents such as leaflets, journals, newspapers, posters and bulletins. Today, many of these materials are curated by community-based archives that continue to identify in some manner both with those movements and their successors. But what might these materials be able to tell us about the 'document work' (to use Ciaran Trace's useful concept) that originally led to their creation and use - and, in a broader sense, the experiences of the movement participants who utilised them as integral components of their political engagement? This paper will explore the meaning of document work within the practices of members of Potere Operaio [Potop], one of the most influential of the revolutionary groups formed in Italy during the late 1960s. The paper concludes with brief reflections as to the implications of this for the present day work of radical community archives.

Wright, S. (2019). The nature of 'document work', and its implications for radical community archives and their holdings. The Journal of Community Informatics, 15, 43-60.

Date submitted: 2018-03-31. Date accepted: 2018-10-31.

Copyright (C), 2019 (the author as stated). Licensed under the Creative Commons AttributionNonCommercial-ShareAlike 2.5. Available at: www.ci-journal.net/index.php/ciej/article/view/1411 


\section{Introduction}

There have only been two world revolutions. One took place in 1848. The second took place in 1968. Both were historic failures. Both transformed the world (Arrighi et al., 1989, p. 97).

The 1960s and 1970s saw a wave of radical social movements across the globe. Some of these were connected to earlier periods of social conflict (above all, by women, workers, and anti-militarists/pacifists), while others were seemingly new. Judged in terms of their stated goals, such movements could well be considered a failure; all the same, their impact continues to be felt. In their wake, a mass of records and other documents - from leaflets, journals, and newspapers to posters and bulletins - were generated. In Italy, where 1968 [Sessantotto] proved to be 'a year that lasted a decade' (Circolo Gianni Bosio, 2006), many documentary materials were destroyed or lost during 'the years of cynicism, opportunism, and fear' (Balestrini \& Moroni, 1997, p. 669) that characterised the 1980s. That some materials nonetheless survived was in large part thanks to a handful of community-based archives - such as the Centro Documentazione di Pistoia - that continued to identify, however critically, with those movements and others that have succeeded them.

In more recent times, some of these texts from forty and fifty years ago have reappeared in print: above all, those penned by individual theorists who rose to prominence during the period (for example, Negri, 2005). Less attention has been paid, by contrast, to those more workaday documents, such as leaflets and newspapers, which thousands of anonymous militants had handled in the course of political activity. What might these materials tell us about the experiences of those who had utilised them as integral components of their political engagement? In particular, what happens when we consider these documents not simply in terms of their content, but also in light of a) their distinctive genre forms, and b) the 'document work' (to use Ciaran Trace's term) bound up with their creation and use? Indeed, as Trace has argued, documents must be understood not only as 'objects that have meaning in context', but also 'as part of the practices that documents, in turn, help to constitute' (Trace, 2016, p. 55).

This paper concentrates on this second question, the routine practices associated with documents within radical social movements of the time. It does so by exploring the nature of document work amongst members of Potere Operaio (Workers Power, nicknamed Potop by its members), one of a number of revolutionary groups formed in Italy during the late $1960 \mathrm{~s}$, before concluding with some brief reflections as to the implications of this for the present day work of radical community archives. In many ways, Potere Operaio was typical of the four or five national organisations that emerged to the left of the Italian Communist Party (PCI) following the mass unrest that gripped Italy's universities and workplaces in 1968 and 1969. Like other such groups, it vied for leadership over the popular turbulence that continued to brew and ferment throughout the following decade. And again, like its political competitors, Potop's membership was largely drawn from students or former students, with a sprinkling of industrial workers: in this instance, most notably from the petrochemical plants of Porto Marghera, near 
Venice. In other ways, the group was quite different to its radical rivals. For one thing, Potere Operaio was somewhat smaller, with strongholds confined to three regions: the Veneto, Tuscany, and Lazio. Most of all, it differed from others in terms of its political perspectives, which were shaped by a distinctively Italian approach to marxism known as operaismo [workerism]. As a consequence, members of Potop spoke and wrote in their own version of leftist dialect [sinistrese], using terminology such as 'class composition', 'refusal of labour', and 'planner-state' that referenced concepts often quite alien to the marxist-leninist common sense then predominant within Italy's far left. While this difference in vernacular made it easier to identify individual militants of Potere Operaio whenever they opened their mouths, it is also true that in so much of their daily routine, the document work of the potoppisti was typical of that within the Italian far left as a whole. As a consequence, examining how the group created and used documents within its practice helps in better understanding that broader experience of half a century ago (Scavino, 2000, p. 83).

Like all of those ensnared by the spell of modernity, members of the political community known as Potere Operaio 'live[d] in a web of documents' (Hartland et al., 2005 , p. 75; see also Ferraris, 2013). At the same time, they also worked with the printed word in a number of particular ways, towards specific purposes. Documents were created (an overarching term that encompasses the acts of writing, setting in type, laying out and printing - each of which needs to be unpacked in its own right) for a number of ends, from informing and/or persuading others, to promoting and/or justifying some course of action. Once created, they needed to be distributed (another overarching term that denotes a range of acts). Finally, after all this, with any luck these documents came to be consumed: studied, discussed and otherwise utilised by readers. In this regard, the exploration of that 'communications circuit' of which Robert Darnton has written with specific reference to the book - a circuit stretching from authors to publishers, printers, distributors, retailers and finally readers - can fruitfully be extended to other documentary forms found within the broader world of the printed word (Darnton, 1982, p. 67; see also Darnton, 2007). Each kind of document work within this communications circuit carries its own specific attributes, while also being connected to other communicative practices within the circuit and beyond. The sections below aim to trace out the rough contours of the communications circuit in and around Potop, to see what might be learned about political engagement in the process.

\section{Producing documents: writing}

...the paper as this collective agitator struck me as an old-fashioned communist idea, to tell the truth. But I believe that Scalzone above all needed to produce a paper like he needed to drink coffee every morning (Roberto Rosso, in Guicciardi, 1988, p. 96).

We can start our survey of document work within Potere Operaio with the question of who in fact conceived of and wrote the group's texts. In part, the answer depends upon which specific materials are under consideration. Like all political organisations of certain size, Potop deployed a full-blown suite of documentary forms, from internal bulletins to posters and pamphlets which is what Wanda Orlikowski and Joanne Bates (1994, p. 542) have called a 'genre repertoire'. If hundreds of activists had at various 
times written local leaflets for Potere Operaio, and many dozens contributed copy to its national publications, rather fewer had a direct hand in the programmatic statements issued in the group's name, let alone the essays that attempted to distil workerism as a distinctive theoretical and political current. In a recent overview of operaismo's evolution, Sergio Bologna (2013, p. 121) suggests that an intricate process of popularisation connected the latter texts with the former:

The first generation of Italian 'workerists' studied and elaborated on Marx's writings between the early sixties and the mid-seventies ... Once broadly received within the political space that was defined as workerism, the fixed reference-points established by such readings and interpretations came to constitute a sort of common ground. They were transformed into a series of 'mental prototypes' and underwent the well-known process of vulgarisation described by Geiger in his writings on intellectual labour. They became slogans, eventually finding their way into the politico-ideological discourse that provided the 'workerist' group with its identity and public image. Then, a new research-effort would be undertaken, again on the initiative taken by an individual, continuing where the last exploration had left off.

Guido Borio (2001, p. 8) has asserted that 'only a very few people' - not all of whom became members of Potop - were ever located at the summit of this process:

three, four, or at most five. They were the subjects who really gave and represented a direction, the driving forces within operaismo: [Mario] Tronti, [Antonio] Negri, [Romano] Alquati, in certain respects Bologna, and maybe someone else.

According to Borio and his fellow authors of the book Futuro Anteriore, this small elite of theorists was linked to the wider movement by what they have called 'a stratum of diffuse militant intellectuality' (Borio, Pozzi \& Roggero, 2002, pp. 27-8; cf. pp. 210ff). Speaking with his own political past in mind, Borio $(2001$, pp. 6,5$)$ has insisted that

The intermediary location is central: it provides a level of continuity, that is of militancy understood as growth and presence not within individual struggles, but within trajectories [percorsi] that elaborate and organise matters with some degree of intention. It has the role of extracting, making evident and providing potentiality to the intrinsically political dimension present within struggles ... this is the central dimension for any project that aims to creates ruptures within capitalist compatibilities, and from these beget [scaturire] a possible anti-systemic alternative.

Within the organisational setting of Potere Operaio, the numbers involved in crafting documents that laid down shared aims and purpose were somewhat greater than 'three, four, or at most five'. For the most part, however, such texts could not command the same sense of gravitas as those produced by the thinkers listed by Borio. But if the documents that were circulated in the name of Potere Operaio were generally of another ilk to the essays in Tronti's book Operai e capitale, it is also true that a quite narrow list of names was to the fore whenever 'tasks and perspectives' were debated within the group. Reading through Potop's press and internal documents, it is clear that time and time again, Negri, Oreste Scalzone and Franco Piperno dominated the stage in debates over direction and tactics, even if space was normally granted for other members to have their say. Given the arenas within which these debates were waged (most notably, the Potere Operaio national conference), another important dimension on the genre front 
is the role that the spoken word - distinctive in form from the mode of expression found in essays or newspaper articles, if less so from leaflets or wall posters - came to assume within these kinds of communicative practices amongst the workerists. The printed rendering of speeches was not overly common in the published outpourings of operaismo during the time of Potop; some of those that do exist, like the extract below from a 1971 speech by Negri, may only have been transcribed from tape recordings years afterwards so that they could be presented as evidence in court proceedings. Whatever the case, such speeches often times bear witness both to the novelty of the organisation's outlook when compared to dominant left traditions in Italy, but equally to the ongoing legacy of those tradition's rhetorical flourishes and cadences:

\begin{abstract}
Because, comrades, what we are setting out to do can mean a great leap forward for the whole movement. What we are planning is something that involves all of us in the most profound way. Comrades, the fundamental instruments of organization are men [sic], they are the militants. Here each of us needs to know that being militants means staking everything (Negri, quoted in Scarpari, 1979, p. 270; see also May, 2013).
\end{abstract}

As for the group's newspaper, much of its copy was produced by a small core of writers, amongst whom Scalzone long played a central role. When the paper was relaunched yet again as a weekly in 1972, it fell to a new circle of scribes to craft the requisite number of columns needed to fill each issue. As a physical artefact, Potere Operaio del lunedi was visually striking, and would go on to win at least one industry design award during its short life. In terms of its content, some effort was made - due in part to the influence of some sympathetic, older journalists working in mainstream media - to render its content more accessible than the rather ponderous writing typically found in Potop's theoretical output. Beyond this, considerable effort was placed in soliciting material from the wider membership, although this task was not without its own challenges. In the words of Massimo D'Alessandro,

Piperno carried forward the political line, mediating between various positions at the national level - although this only occurred on important occasions. In reality we solicited various pieces from the branch offices, by telephone. Then we as editors stitched the articles together. Often we found ourselves mediating things that struck us as too extremist ... (in Grandi, 2003, p. 213).

With divisions within Potop becoming more acrimonious by early 1973, control over the organisation's press was one of the more obvious fronts where war was waged between the competing factions. And if one camp was ultimately able to secure its hold upon the weekly publication, the latter's increasingly poor production standards, combined with the growing length of time between each issue's publication, made it ever more clear that Potere Operaio as a group was by then on its last legs.

\title{
The physical production of documents
}

Without its own printing press, many documents within Potere Operaio's genre repertoire could only be manufactured by outside entities. Books, periodicals, pamphlets: each depended in certain ways upon commodified systems of production and distribution. This reliance upon commercial firms that were, with a few important exceptions, largely indifferent to the group's project bore certain consequences for its 
documents' creation and use. Scalzone's memoirs, published for the twentieth anniversary of 1968, are enlightening on this score. Finding the money to support Potere Operaio's newspaper was a challenge from start to finish, he relates, so the preparedness of the leftist publisher Giangiacamo Feltrinelli to pledge his bookshop chain to buy 'five thousand copies of the paper every week, sight unseen' must have been very handy indeed. Despite this, publication was forced to cease temporarily at the end of November 1969 due to a lack of money, the first of a number of such breaks during the newspaper's lifetime (Scalzone, 1988, pp. 136, 151, 159).

Other kinds of documents could be and were produced in-house: first and foremost, leaflets for external agitation, and internal materials intended for the eyes of members only. Leaflets in particular were a staple of local political work, with branches regularly expected to write and print their own flyers for distribution at the beginning or end (sometimes both) of the shift in some nearby factory (Grandi 2005, pp. 115-116). As in other revolutionary organisations of the time, the internal division of labour involved in the creation of documents was often revealing. Potere Operaio was not immune from the phenomenon of 'gestetner angels' [angeli del ciclostile], an expression coined in the 1960s student movement to designate the activity of those (typically women) engaged in 'behind-the-scenes support work for those (mostly men) who had a public presence as leaders, speakers, and writers' (Barkan, 1984, p. 31). On this front, the words of Stefania Sarsini (in Grandi, 2005, p. 290) suggest that the gender relations within Potop were then par for the course within the Italian far left as a whole:

Lucia, despite her militancy, always remained Scalzone's woman, as I was Verità's woman, and Grazia Zermann was Daghini's woman: we were all 'the woman of'. Our identity as persons didn't exist, and this made militancy all the harder. No documents were elaborated by women. And the 'gratification' of gestetnering leaflets until late at night, or of cleaning a branch office soiled by the [remnants of] sandwiches and cigarette stubs smoked by dear [male] comrades intent on staying awake so that they could elaborate revolutionary theories, was certainly rather minimal for a revolutionary militant!

\section{Distributing documents}

The National Secretary reminds comrades that the militant diffusion of the paper must be considered the first task of each Potere Operaio branch (Potere Operaio, 1972).

Once printed, documents needed to be distributed. When it came to the circulation of the weightiest of the group's texts, which typically assumed book form, the commercial realities of dependence upon market mechanisms were never far away. During the latter part of Potere Operaio's existence and beyond, the Feltrinelli book column 'Materiali marxisti' and the pamphlet series Opuscoli marxisti acted as crucial conduits for the dissemination of workerist theoretical ruminations (Moroni, 1996). No doubt Negri (1980, p. 260) was exercising his characteristic sarcasm at the time, but there was also an uncomfortable truth in his admission of 1979 that it had been years since he had addressed 'a Movement assembly: I'd be booed off the stage. I have instead written books, articles, pamphlets which I have sold: my rapport is organic with the market'. 
The often uneven apportionment of print media within the Italian far left of the early 1970s held ramifications of its own. Two of the largest groups, Lotta Continua and Manifesto, each had their own daily newspaper by 1972; in 1974 Avanguardia Operaia became the third. By contrast, the best that their many smaller radical competitors could manage was a weekly publication. Some of the implications of this in terms of document work were made clear when a number of female comrades chose to abandon Potop altogether and establish a new organisation in 1972. In response, a section of the group's male membership attempted to disrupt a seminar organised by Lotta Femminista at the University of Rome: breaking windows, hurling water-filled condoms, and injuring some of the participants. While Lotta Femminista (1972a) circulated a leaflet a few days after the attack, its efforts to make its views known on the national level were largely dependent upon letters sent to publications associated with other sections of the far left: in particular, the eponymous daily papers belonging to Lotta Continua and Manifesto. In each case, furthermore, Lotta Femminista's missive had to endure a certain degree of editorialising from the publication in question. Without a daily publication to its name, the local leadership of Potere Operaio was likewise forced to use the newspaper of a rival organisation to convey its stance on the matter. The resulting statement is a curious text, claiming to take Lotta Femminista's views on class exploitation seriously and threatening 'disciplinary procedures' against those who attacked the women, whilst being unable to resist a sideswipe at 'the comrades of Manifesto' for trying to capitalise on Potere Operaio's woes (Lotta Femminista, 1972b, pp. 11-20).

Making Potop's weekly paper available to the general public meant securing distribution through the country's dense network of newsstands. Getting issues to the news kiosks depended in turn on a contract with the state railway company (Grandi, 2003, p. 216). Making the organisation's paper available to workers and other leftists relied on a different practice: what then was called 'militant' distribution. As anyone who has been taken part in far left politics knows only too well, selling an organisation's publications is one of the key duties that unites members of a movementwide ceto politico [political class] who may otherwise be deeply divided along lines of ideology, perspective, and group loyalty. For Alessandra De Perini, casting her mind back to the days of 'selling the paper Potere Operaio' conjured up 'a contradictory image of myself: a young woman of twenty, twenty-one, in a mini-skirt, distributing "Democracy is the rifle in the workers' hands, on the workers' shoulders" '. This memory was also inseparable from her sense of identity at that point in time: what it then meant to be 'in quotation marks, a "militant" ... At the beginning, the adhesion was complete, total' (in Sacchetto, 2009, p. 197).

\section{The use of documents in political work}

Within Potop itself, much was made of the need for members to study a host of documents, whether written by the group's leading members, or by classic authors old and new (which in this case meant Marx, Lenin, and Tronti). Interviewed in 2001, Ferruccio Gambino - who had helped organise seminars on Marx in Padua after 1968, both at the university and outside it (Grandi, 2005, p. 28) - would suggest that 
Explaining the Grundrisse via Rosdolsky, in certain peripheries abandoned to their own devices by the regime of that time, might seem a mistaken ambition - and even back then, amongst ourselves, we sometimes waxed ironic over this. But the principle and dedication were sacrosanct, and when these fell away by dint of force majeure at the end of the 1970 s, the disorientation that followed was frightening ... In Potere Operaio, militants who did not dedicate time to study were bound to fail, even if they were able to produce some sporadic fireworks at the local level. There was a part of one's life in which you could not simply wander around leafleting or showing yourself to be hyperactive: it was also necessary to reflect and to study (Gambino, 2001, p. 10).

Studying was a prerequisite for other activities as well, amongst them the possibility of taking part in the organisation's internal debates. As Andrea Leoni remembered, 'There was almost a snobbishness in avoiding simplifications in interventions and writings. If you wanted to understand and participate you had to study, there were no shortcuts' (in Grandi, 2005, p. 175). The same held for making sense of the world outside. Another former Roman militant, Massimo Casa, has stressed the importance of carefully appraising prospective sites of political intervention:

You needed to know about the organization of work in the factory, about pay rates, hours and bonuses, about foremen and hierarchies, you had to learn how to construct a stable organization and clarify in practice [nei fatti] why we were different from the union. But above all you needed to understand the class composition in every situation. Class composition was for us what the philosopher's stone had been for sixteenth century alchemists. They set themselves the problem of finding the formula for extracting gold; we shared their intellectual intensity, their artisanal industriousness, and the same risky pleasure. So when we went anywhere - a school, a factory, a university faculty, a neighbourhood - we sought to identify, and go and speak with, that part of it that was the central motor of social insubordination (in Grandi, 2005, pp. 91-2).

In order, therefore, to understand the disposition of the contemporary working class, along with its potential for social conflict, members of Potop were dependent not only upon their own observations and the contacts they had made with sympathetic workers or residents, but also upon a host of printed materials. These latter ranged from the minutiae of pay slips and industry-specific contracts, to foundational works like the first volume of Marx's Capital, with its detailed account of the working day and the place of machinery within large-scale industry. 1 Offering a bridge between these two very different kinds of texts were printed materials emanating from the rapidly evolving operaista canon, particularly those that made claims to framing strategic perspectives. Yet for all the enthusiasm that essays or pamphlets penned by their most prominent

\footnotetext{
1 Here is how one participant later wrote of this process of collective study: 'I decided to attend a seminar that Ferruccio Gambino was holding in the Faculty of Political Sciences, in which they discussed Das Kapital by Karl Marx. I began to understand the meaning of many concepts and categories that were used in the movement, but which had for me at that time a vague meaning. The most important things I learned in Ferruccio's class on Marx were the basic concepts of class, capital, working class, labor, productive and unproductive labor, surplus value, and so on, but reshaped in a way that could effectively capture all the changes produced by capital in the history of society after Marx, and especially in the society in which we lived. The consequent reading of society proposed by Ferruccio was very different from the vision of orthodox Marxism that the Communist Party was elaborating and proposing' Fortunati, 2013.
} 
theorists might generate amongst Italian workerists, there was also general agreement around the relative difficulty of many of the concepts in use, as well as the language used to express them. Patrizia Violi (1977, p. 40) was not alone in observing of the newspaper Potere Operaio that 'not only the average reader, but probably also many militants of Potere Operaio itself, would find decoding the journal difficult to the point of absurdity'. And yet, if Francesco Bellosi is to believed, that struggle with the printed word, if successful, could bring its own rewards:

I understood that Toni Negri and the others were right, they were the only ones able to read what was happening [in the factories]. But they spoke in a difficult manner, and they wrote like German philosophers. It took a lot of effort to translate those languages into something I could understand. In Como a group of intellectuals (including worker intellectuals) pondered matters: older than me, they had followed and participated in the whole evolution of operaismo, from Quaderni Rossi to Classe Operaia. They supplied me with all that theoretical material, which I spent whole days going over. And finally it all became clear (in Grandi, 2005, p. 25). 2

Alongside the practices discussed thus far, documents could be worked with in ways that are sometimes less than obvious. The collection of essays by Tronti brought together in the 1966 volume Operai e capitale was the single most important workerist document of the 1960s, a formative text for successive generations of Italian operaisti. This book, Claudio Greppi once declared, was 'the bible of Potere Operaio'. Having quickly gone out of print, its circulation to a wider audience then largely depended upon the initiatives of amateur enthusiasts, at least some of whom produced 'horrendous photocopies that almost nobody could read' (Greppi, 2000, p. 8; Grandi, 2005, p. 92 cf. pp. 66, 74). And finally, for a little light relief, we may note the somewhat unusual role that the book came to play within the love life of Valerio Morucci, who was then involved with Potere Operaio's rudimentary clandestine apparatus. Morucci relates that on at least one occasion, Operai e capitale served as both an aphrodisiac and a would-be instrument of seduction:

Those words inebriated me, and I hoped that they would inebriate her as well. So I sat down on the couch, with her stretched out, my hand in her hair, and I read her a passage. 'But in any case, whoever said that this was the pinnacle of human civilisation? Large scale industry and its science are not the prize in the class struggle - they are the very terrain of that struggle. And so long as that terrain is occupied by the enemy, we need to fire upon it, without tears for the roses'. I was close to orgasm, but for her: nothing. It was like I was reading Little Red Riding Hood ... (Grandi, 2005, p. 74; Morucci, 1999, pp. 69, 70).3

\section{Potere Operaio's documents in the hands of the judiciary}

Perhaps the most far-reaching unintended consequence of Potere Operaio's document work was the use made of workerist publications by sections of the judiciary in their efforts to criminalise revolutionary politics throughout the peninsula. Within months of Potere Operaio's appearance, the comrade registered as legally culpable for its

2 Quaderni Rossi and Classe Operaia were journals produced during the 1960s.

3 This passage from Tronti would also inspire a poem by Nanni Balestrini (1969). 
publication had been sentenced to seventeen months in prison on the charge of 'instigating the workers of all Italy to revolt against the state, and in particular the metalworkers of FIAT Turin to damage vehicles' (Potere Operaio, 1969). As the thenMinister of the Interior put it, if politically-motivated property destruction was in general on the rise,

More insidious still for democratic public order is the propaganda of violence as a method of political struggle advanced by these groups, and Potere Operaio in particular, through a series of regular and irregular periodicals, posters and leaflets (quoted in Grandi, 2003, p. 110).

As was often the case in the world of Italian far left publications, the individual who provided this legal cover was not even involved in the journal's production, although he had been an important figure in operaismo's evolution within the Veneto, and had played the same role earlier in the 1960s for the workerist journal Classe Operaia. As Scalzone explained, the offending headline - 'Yes to workers' violence' - had been his, but Article 57 of the penal code demanded that the paper's 'direttore responsabile' rather than its editor be placed in the dock: 'I had never met nor seen [Francesco] Tolin - we had only spoken on the telephone. When we did meet I could only apologise, because it was my fault that he had ended up inside' (Grandi, 2005, p. 330; Grandi, 2003, pp. 108-9). This would not be the only such case in the group's history: a couple of years later, Emilio Vesce was likewise imprisoned in connection with its press, found guilty in that instance of contempt of court (Grandi, 2003, p. 215).

By the early eighties, with the mass arrests against the armed groups and their alleged supporters in Autonomia in full swing, the most forceful reading of workerist documents and the connotations they might bear was that put forward by the magistrate Pietro Calogero, the central architect of the '7 April' mass arrests of 1979. After the initial charges of involvement in the killing of Aldo Moro fell apart, much of the judges' focus shifted to the period - long before Autonomia became a movement of any consequence - when Potere Operaio proclaimed the necessity of building the armed party. Suddenly Negri and co-defendants found themselves facing trial not so much for supposed membership of the Brigate Rosse, but for having attempted to stage an insurrection back in 1971. For many individuals, the mere fact of having once belonged to Potere Operaio now became grounds for investigation (Bugno, 1981). Through all these twists and turns, Calogero assigned a particular importance not only to what certain documents said, but also to who possessed them and in what form. A significant component of his accusations against Negri and others revolved around textual analysis. But this in itself was not enough: the physical presence of documents was equally seen as a crucial means of identifying an individual's location within the tangled networks said to bind the only-apparently fractious autonomist collectives, together with the major armed groups, within a single web of social subversion. As Calogero (2010, p. 134) later recounted,

I explained to the collaborators from Digos4 the significance of the most recurrent terms in the language of extreme left militants ('autonomy', 'counterpower', 'combattent vanguards', 'destabilisation', 'destructuring'). I also drew their

4 DIGOS is a national police body responsible, amongst other things, for combating terrorism. 
attention to the importance, particularly in house searches, of tracking down documentary materials (manuscripts, communiqués, resolutions, political programs, journals and various printed matter) rather than a weapon. Arms, I made clear, could reveal to us at most a suspect's role as a subordinate or follower, whereas documents could indicate the suspect's leadership rank [rango direttivo] and unveil important organisational events and associations concerning the group to which they belonged.

Even more creatively, on at least one occasion, the draft version of a document later circulated in Potere Operaio's press would be presented instead as a hitherto unknown clandestine text, uncovered and brought to public attention only thanks to the diligence and vigilance of the prosecution (Comitato 7 aprile, 1979, pp. 140-1). In this instance, as with the so-called 'Calogero theorem' 5 more generally, the group's documents were used by the sections of the judiciary less to establish the veracity of criminally culpable activities, than to reread the past decade of mass social conflict as ultimately the handiwork of a few powerful individuals able to manipulate events from behind the scenes.

\section{Documents, identities, and trajectories}

We can conclude this discussion of 'document work' in Potop by considering the close association between certain genres and the political identity of groups and individuals. Circles grouped around the production of a journal were commonplace in the Italy in the decade or so following 1956 - so common, in fact, that the period is often referred to as 'the years of the reviews'.6 Indeed, after 1968 many organisations of the Italian New Left shared a name with their primary publication: Lotta Continua, Potere Operaio, Manifesto, Avanguardia Operaia (at least in its early days, before the establishment of the daily newspaper Quotidiano dei lavoratori). Indeed, within the movement of Autonomia in the 1970s, some groups (Collettivi Politici Operai, Comitati Comunisti per il potere operaio) were best known by the name of their papers (Rosso, Senza Tregua), not unlike a number of dissident Communist groupings back in Resistance times (Bandiera Rossa, Stella Rossa) (Peregalli, 1995). More unusual, but equally striking, was the temporary nomenclature assigned to a small Turin-based formation, before its members finally hit upon the moniker of Collettivo Lenin:

Lacking a name, [they] began to distribute some leaflets and pamphlets. Someone jokingly dubbed the group 'Read and pass on', because this was typically the signature/slogan that closed their leaflets (Allare et al., 2009, p. 66; cf. Rieser, 2001, p. 6).

With newspapers assigned such a key place in militants' shared identity, did this also mean that documents penned by individual members were similarly beholden to the organisation as a whole? If Franco Berardi (2000, pp. 4-5) is to be believed, the answer

\footnotetext{
5 The 'Calogero theorem' alleged that the mass movement of Autonomia and terrorist organisations such as the Brigate Rosse were twin emanations of Negri and his closest associates. Pacifici, 2015 discusses various perspectives developed by the judges in the 7 April case.

6 See for example the essays collected in Classe 17 of June 1980, organised around the theme of 'The years of the reviews (1955-1969)'.
} 
to this question within Potop was one factor that led him to drift away from the group in the early 1970s:

The Spring of 1970 saw the publication by Feltrinelli of my booklet entitled Contro il lavoro (Against work), which referred above all to the discussion within Potere Operaio, and had an explicitly anti-leninist character, against the [recent] change in line. In that period (I remember precisely on what occasion) Toni Negri - before the book had come out, so while it was with the typesetter - said to me: 'I've read your booklet, you should have discussed it first within the organization.' I told him that it had never even crossed my mind to do something like that. The whole thing was very amicable, he didn't reproach me; he simply noted that a militant needed to behave in a certain way. I noted instead that it seemed to me that if someone wrote something, it was their business, and not the organisation's.

Berardi $(2000, p, 5)$ has gone further, arguing that the day-to-day sensibilities of many members were actually often at odds with Potere Operaio's formal pronouncements, whether set out in print or otherwise:

...on the one hand an official discourse was made at congress, at meetings, in other words in the places of political discussion, where the basic assumption was a leninist type of hypothesis (therefore the construction of the party structure, the identification of the organization as the place that in some way must lead the movement) ... however, in unofficial discussion, the self-perception of the PO militant was as a spontaneist.

Finally, documents - or indeed their absence - could also provide significant markers in the identity of individuals, signposts for the choices made at decisive moments in their life history. One of Bologna's lingering regrets, he stated in 2001, concerned the manner in which he had quit both his leadership position and Potere Operaio itself just a year or so after the group's foundation:

More youths paid dearly because they weren't able to see a public clarification: if there had been a public clash between me and them [Negri and Piperno] where it was said 'I agree on this and that', it would have put things in black and white, and young comrades would have had something to grapple with. Instead it was ambiguous, I left without producing what we could call an 'exit' document, for the usual reason: 'the situation is delicate, let's not create difficulties, if I say why I don't agree, I'll have to reveal publicly proposals that are still nebulous, with the implicit risk of betrayal' (Bologna, 2001, p. 4).

As one of those who remained in the rump of Potop after Negri and others left to join the autonomist movement, Giovanni Contini (in Grandi, 2005, p. 84) recalled a similar moment of truth, marked in his case by the arrival sometime in 1974 of

...a national document, in which it was said that the situation was mature for an insurrectional turning point, that the revolutionary party had to commit itself to carrying into the future the struggles and hopes of a mass worker now certainly destined for defeat. After years of militancy, of frenetic activism, always immersed in the language of our sect, I remember that it was not easy to criticise that document ... Over the years I have thought that [unlike others] we were lucky to 'disassociate' ourselves in time, before making certain experiences and committing irreparable actions ... we were very lucky ... to understand from that document that the story was now over. 


\section{In conclusion: some brief implications of document work for radical archives}

I hope that this brief introduction to Potere Operaio's genre repertoire and communications circuit has helped not only in making sense of how such documents were created and used, but has also provided some useful insights into the practices of an important ensemble of political militants from the 1960s and 1970s in Italy. While Kristin Ross (2015) in her book Communal Luxury reminds us that the past does not 'give lessons', there are nonetheless ways in which its critical evaluation might prove 'untimely' in Nietzsche's (1997, p. 60; cf. De Lorenzis, 2010) sense: 'that is to say, acting counter to our time and thereby acting on our time and, let us hope, for the benefit of a time to come'. For not only is historical research from this perspective 'always a self-critique' (Karl Heinz Roth, quoted in De Lorenzis, 2010, p. 160), but as Massimiliano Tomba (2013, p. 54) has argued, 'History does not, in reality, stand before the materialist historian as an object to be represented objectively, "as it really happened", but as a Kampfplatz in which to intervene'.

As is well known, to be radical means 'to go to the root of things'. In this sense, perhaps the project of a 'radical archives' able to support such research is less about the content it might hold, and more about the ways in which that material is organised and presented. If Trace (2016, p. 55) is right in arguing that documents must be understood not only as 'objects that have meaning in context', but also 'as part of the practices that documents, in turn, help to constitute', then perhaps those responsible for a radical archives must strive, so far as they can, to devote particular attention to the kinds of contextual information that can be provided about its holdings.

Doing this well is a labour-intensive process, and there is always the risk of drawing energy and resources away from other processes essential to the maintenance of an archive's collection. Then again, the potential rewards in terms of making an archive's holdings relevant to its interlocutors are immense. Here, therefore, are a few suggestions. First of all, an extended use of the humble finding aid. Existing collections at a number of movement-related archives in Italy are typically physically organised as an individual's papers - and there is a good deal of sense behind why that might be so. This is the case, for instance, with the Centro studi Piero Gobetti in Turin (http:// www.centrogobetti.it/), the source of many of the Potere Operaio leaflets that I am using for my current research. While detailed listings are available online for each such deposition within the Fondo Marcello Vitale there, 7 what would also be very useful are further overarching guides that seek to provide pointers as to how the genre repertoire of an organisation like Potop might be reconstructed. This approach is something that, albeit in a different context, the Australian Lesbian and Gay Archives (www.alga.org.au) has attempted with some success through the thematic guides it has begun to produce.

7 See http://catalogo.archividelnovecento.it/scripts/GeaCGI.exe?

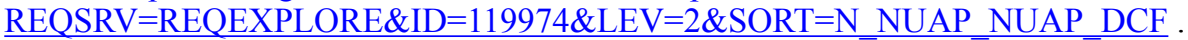


A second suggestion comes from the late Primo Moroni who, together with Nanni Balestrini, was responsible for one of the best anthologies of Italian social movement documents from these years. In his view (Moroni, 1999, pp. 32-3), a critical reconstruction of the period requires that the printed word be evaluated alongside a series of recorded interviews that encourage

individual militants to recount - for hours if need be - their subjective history, their perception of the world, their relations with institutions, their understanding of the political context.

Of course, oral sources need to be treated as carefully as textual sources - all the more so, when they record observations made with hindsight (Boccia, 2011). Again, if such an undertaking demands considerable effort, recent years have seen a number of important studies that provide important oral accounts of the period, including the crucial perspectives of so-called 'rank and file' activists (Circolo Gianni Bosio, 2006). On the other hand, there is a certain urgency here, with militants of the 1960s and 1970s beginning to pass away - as was the case recently of Mario Dalmaviva, who had played a crucial role in the history of Potere Operaio, beginning with its intervention amongst FIAT workers during the Hot Autumn of 1969 (Bologna, 2016).8

As a final, more ambitious example to consider, there is the series of books produced by the Centro Documentazione di Pistoia. Within this, pride of place belongs to two guides edited by the late Attilio Mangano, which offer detailed and thoughtful commentaries through which to frame the journals of the period held by that archive (Mangano, 1998b; Mangano \& Schina, 1998; see also Gori n.d.). For our purposes, these guides are noteworthy for how they address the documents in question, given that they 'avoid a pure and simple history of the reviews as a "cultural history" of their principal ideas', in favour of an approach that takes seriously "the relationship between politicisation and daily life', and thus 'the multiplicity of flesh and blood individuals, and the extraordinarily capillary way in which they were involved in the movement, starting from their workplaces, within institutions, the family, and every form of associated life' (Mangano, 1998a, p. 19; Mangano, n.d., p. 9; Pier Paolo Poggi, cited in ibid.).

In all of this, important lessons can be taken from interpretative frameworks such as continuum discourse, starting with Leisa Gibbons' Culture Heritage Continuum Model, which adds the dimension of curation to established continuum thinking concerning cultural practices (Gibbons, 2014, p. 73). Whether or not the suggestions raised above prove useful, the case remains that much needs to be done to further the pluralisation of materials held in radical archives. Indeed, without such efforts to extend 'the use or construction of records beyond management and organisation and towards use as a collective memory' (Gibbons 2014, p. 73), it will prove extremely difficult to challenge 'the enormous condescension of posterity' (Thompson, 1980, p. 12) with which the fiftieth anniversary of 1968 is likely to be greeted in a year's time. For despite the efforts of a small band of independent publishers and individual enthusiasts utilizing

8 Those of Mario Dalmaviva's papers deposited in the Fondo Marcello Vitale are listed at http:// catalogo.archividelnovecento.it/scripts/GeaCGI.exe?

$\underline{\text { REQSRV }=\text { REQEXPLORE } \& I D=120085 \& L E V=3 \& S O R T=N \text { NUA NSF DCF }}$ 
both print media and web-based archives, the great bulk of the printed materials of the 1960 s and 1970s are still difficult to access. As a consequence, the portrayal of Sessantotto and its aftermath, not as successive waves of massive social conflict, but simply a private war waged by bloodthirsty, isolated cliques (the so-called 'years of lead') too often goes unchallenged in Italy and beyond. Given this, as Marco Scavino (1996, p. 10) has argued, recovering and evaluating such documents is important not only in terms of historiography, but above all because

...every initiative that serves to make these documents known constitutes therefore an important contribution to historical awareness of that season of movements that, variously evoked or exorcised in current political debate, continues to represent one of the unresolved nodes of democratic Italy's recent history.

\section{Acknowledgements}

I would like to thank Amanda Cossham for copy-editing an earlier version of this essay.

\section{Bibliography}

Allare, C. et al. (2009). 1969/1977 Lotte operaie a Torino. L'esperienza dei Cub, comitati unitari di base. Milan: Edizioni Punto Rosso.

Arrighi, G., Hopkins, T. \& Wallerstein, I. (1989). Antisystemic movements. London: Verso.

Balestrini, N. (1969). No Tears for the Roses, translated by Peter Valente. Retrieved July 5, 2017 from http://versobooks.tumblr.com/post/146300256998/no-tears-for-the-roses-a-poem-by$\underline{\text { nanni }}$

Balestrini, N. \& Moroni, P. (1988). L'orda d'oro. Milan: Sugarco.

Barkan, J. (1984). The Genesis of Contemporary Italian Feminism. Radical America 18(5): 31-36.

Berardi, F. (2000). Intervista a Franco "Bifo" Berardi - 19 novembre 2000. Now in the CDROM accompanying Borio, G., Pozzi, F. \& Roggero, G., Futuro anteriore. Dai "Quaderni Rossi" ai movimenti globali: ricchezze e limiti dell'operaismo italiano. Rome: DeriveApprodi.

Boccia, M. C. (2011). Valerio Verbano: Una ferita ancora aperta. Rome: Castelvecchi.

Bologna, S. (2001). Intervista a Sergio Bologna. Now in the CD-ROM accompanying Borio, G., Pozzi, F. \& Roggero, G., Futuro anteriore. Dai "Quaderni Rossi" ai movimenti globali: ricchezze e limiti dell'operaismo italiano. Rome: DeriveApprodi.

Bologna, S. (2013). Workerism: An Inside View From the Mass-Worker to Self-Employed Labour. In M. van der Linden \& K. Heinz Roth (Eds.), Beyond Marx: Confronting LabourHistory and the Concept of Labour with the Global Labour-Relations of the Twenty-First Century) (pp. 121-43). Leiden: Brill.

Bologna, S. (2016). Marione, il grande. Retrieved July 5, 2017 from http:// www.euronomade.info/? $\mathrm{p}=7583$

Borio, G. (2001, Intervista a Guido Borio - 27 ottobre 2001. Now in the CD-ROM accompanying Borio, G., Pozzi, F. \& Roggero, G., Futuro anteriore. Dai "Quaderni Rossi" ai movimenti globali: ricchezze e limiti dell'operaismo italiano. Rome: DeriveApprodi. 
Borio, G., Pozzi, F. \& Roggero, G. (2002). Futuro anteriore. Dai "Quaderni Rossi” ai movimenti globali: ricchezze e limiti dell'operaismo italiano. Rome: DeriveApprodi.

Bugno, F. (1981, August 2). Sindacato-terroristi categoria Br. L'Espresso: 6-10.

Calogero, P. (2010). La testimonianza. In P. Calogero, C. Fumian \& M. Sartoni, Terrore rosso. Dall'autonomia al partito armato. Rome: Laterza.

Circolo Gianni Bosio (2006). Un anno durato decenni. Vite di persone comuni prima, durante e dopo il '68. Rome: Odradek.

Comitato 7 aprile e collegio di difesa (Eds.) (1979). Processo all'Autonomia. Rome: Lerici.

Darnton, R. (1982). What is the History of Books? Daedalus, 111(3): 65-83.

Darnton, R. (2007). "What is the History of Books?" Revisited. Modern Intellectual History 4(3): 495-508.

De Lorenzis, A. (2010). Appunti sui fondamenti della "storia militante". In C. Bermani (Ed.), La rivista "Primo Maggio" (1973-1989) (pp. 151-61). DeriveApprodi: Rome.

Ferraris, M. (2013). Documentality: Why It Is Necessary to Leave Traces. Translated by Richard Davies, New York: Fordham University Press.

Fortunati, L. (2013). Learning to Struggle: My Story Between Workerism and Feminism. Retrieved July 5, 2017 from http://viewpointmag.com/2013/09/15/learning-to-struggle-mystory-between-workerism-and-feminism/.

Gambino, F. (2001). Intervista a Ferruccio Gambino. Now in the CD-ROM accompanying Borio, G., Pozzi, F. \& Roggero, G., Futuro anteriore. Dai "Quaderni Rossi" ai movimenti globali: ricchezze e limiti dell'operaismo italiano. Rome: DeriveApprodi.

Gibbons, L. (2014). Culture in the continuum. YouTube, small stories and memory-making. Unpublished doctoral disseration, Monash University.

Gori, C. (Ed.) (n.d.). Politica e movimenti: 1966-1996. Catalogo dei periodici della Biblioteca del Centro di Documentazione di Pistoia. Pistoia: Edizioni del Comune di Pistoia, Centro di Documentazione di Pistoia.

Grandi, A. (2003). La generazione degli anni perduti. Storie di Potere Operaio. Turin: Einaudi.

Grandi, A. (2005). Insurezzione armata. Milan: Rizzoli.

Greppi, C. (2000). Intervista a Claudio Greppi - 23 settembre 2000. Now in the CD-ROM accompanying Borio, G., Pozzi, F. \& Roggero, G., Futuro anteriore. Dai "Quaderni Rossi" ai movimenti globali: ricchezze e limiti dell'operaismo italiano. Rome: DeriveApprodi.

Guicciardi, L. (1988). Il tempo del furore. Il fallimento della lotta armata raccontata dai protagonisti. Milan: Rusconi.

Hartland, R., McKemmish, S. \& Upward, F. (2005). Documents. In S. McKemmish, M.Piggott, B. Reed \& F. Upward (Eds.), Archives: Recordkeeping in Society (pp. 75-100). Wagga Wagga: Centre for Information Studies, Charles Sturt University.

Lotta Femminista (1972a, July 10). Il 7 luglio alla Facoltà di Magistero ... Retrieved July 5, 2017 from http://www.femminismoruggente.it/femminismo/pdf/1972/roma/ volantino $10-7-72 . p d f$

Lotta Feminista (1972b). L'Offensiva. Quaderni di Lotta Femminista 1. Turin: Musolini editore.

Mangano, A. (n.d.). Presentazione. In C. Gori, (Ed.), Politica e movimenti: 1966-1996. Catalogo dei periodici della Biblioteca del Centro di Documentazione di Pistoia (pp. 8-13). Pistoia: Edizioni del Comune di Pistoia, Centro di Documentazione di Pistoia. 
Mangano, A. (1998a). Le riviste degli anni Settanta: gruppi movimenti e conflitti sociali. Rome: Massari editore; Pistoia: Associazione Centro di Documentazione, Pistoia.

Mangano, A. (1998b). Presentazione. in Attilio Mangano \& Antonio Schina, Le culture del Sessantotto: gli anni sessanta le riviste il movimento (pp. 18-20). Rome: Massari editore; Pistoia: Associazione Centro di Documentazione, Pistoia.

Mangano, A. \& Schina, A. (1998). Le culture del Sessantotto: gli anni sessanta le riviste il movimento. New extended edition. Rome: Massari editore; Pistoia: Associazione Centro di Documentazione, Pistoia.

May, M. (2013). Soapbox Rebellion: The Hobo Orator Union and the Free Speech Fights of the Industrial Workers of the World, 1909-1916. Tuscaloosa: University of Alabama Press.

Moroni, P. (1996). Vita, morte e miracoli dell'underground: Intervista con Primo Moroni. In S. Dazieri (Ed.), Italia overground: mappe e reti della cultura alternativa (pp. 17-50). Rome: Castelvecchi.

Moroni, P. (2009). Storia vissuta. Sinistra militante e storiografia. In P. Moroni \& IG Rote Fabrik (Eds.), Le parole e la lotta armata. Storie vissute e sinistra militante in Italia, Germania e Svizzera (pp. 23-33). Milan: ShaKe.

Morucci, V. (1999). Ritratto di un terrorista da giovane. Casale Monferrato: Piemme.

Negri, A. (1980). I, Toni Negri. semiotext(e) 3(3): 254-61.

Negri, A (2005). Books for Burning. Between Civil War and Democracy in 1970s Italy. London: Verso.

Nietzsche, F. (1997). Untimely Meditations. Cambridge: Cambridge University Press.

Orlikowski, W. \& Yates, J. (1994). Genre Repertoire: The Structuring of Communicative Practices in Organizations. Administrative Science Quarterly 39(4): 541-574.

Pacifici, G. (2015). Giudici o storici? Il "caso 7 aprile". Zapruder 37: 96-103.

Peregalli, A. (1995). The Left Wing Opposition in Italy During the Period of the Resistance. Revolutionary History 4(5). Retrieved July 5, 2017 from http://www.marxists.org/history/ etol/revhist/backiss/vol5/no4/peregalli.html

Potere Operaio (1969, November 27). Contro la repressione stato-capitale liberiamo Tolin e gli altri compagni. Potere Operaio 10, p. 2.

Potere Operaio (1972, 29 October). Comunicato della Segretaria nazionale di Potere Operaio. Potere Operaio del lunedi 16, p. 3.

Rieser, V. (2001). Intervista a Vittorio Rieser. Now in the CD-ROM accompanying Borio, G., Pozzi, F. \& Roggero, G., Futuro anteriore. Dai "Quaderni Rossi” ai movimenti globali: ricchezze e limiti dell'operaismo italiano. Rome: DeriveApprodi.

Ross, K. (2015). Communal Luxury: The Political Imaginary of the Paris Commune. London: Verso.

Sacchetto, D. (2009). Esperienze di classe. In D. Sacchetto \& G. Sbrogiò (Eds.), Quando il potere è operaio (pp. 166-287). Rome: Manifestolibri.

Scalzone, O. (1988). Biennio Rosso. Milan: Sugarco Edizioni.

Scarpari, G. (1979). Processo a mezzo stampa: il "7 aprile". QUALEgiustizia 51, 228-92.

Scavino, M. (1996). Introduzione. In L. Lanzardo, Cronaca della Commissione operaia del movimento studentesco torinese dicembre 1967-maggio 1968 (pp. 7-10). Pistoia: Centro di documentazione Pistoia Editrice. 
Scavino, M. (2000). "Agnelli ha paura e paga la Questura". Il '68 e i movimenti di estrema sinistra. In C. Ottaviano \& P. Soddu (Eds.), La politica sui muri: I manifesti politici dell'Italia Repubblicana 1946/1992 (pp. 81-104). Turin: Rosenberg \& Sellier.

Stewart, C., Smith, C. \& Denton, R. (2012). Persuasion and Social Movements. Sixth Edition. Long Grove: Waveland Press.

Thompson, E. P. (1980). The Making of the English Working Class. Harmondsworth: Penguin.

Tomba, M. (2013). Marx’s Temporalities. Leiden: Brill.

Trace, C. (2007). Information creation and the notion of membership. Journal of Documentation, 63(1), 142-163.

Trace, C. (2016). Ethnomethodology. Journal of Documentation 72(1): 47-64.

Violi, P. (1977). I giornali dell'estrema sinistra. Milan: Garzanti. 